\title{
Effect of land configuration ways on soil moisture and sesame seed yield in Ethiopia
}

\author{
Goitom Teame (D) ${ }^{1}$, Alemtsehay Tsegay (D) ${ }^{2}$, Dawit Weldearegay (iD) 1* \\ ${ }^{1}$ Tigray Agricultural Research Institute, Humera Agricultural Research Center, Crop Department, Humera-Ethiopia \\ ${ }^{2}$ Department of Dryland Crop and Horticultural Science, Mekelle University, Mekelle-Ethiopia
}

\section{ABSTRACT}

Sesame is an erect herbaceous annual plant with both single-stemmed and branched growth habits. Sesame seed yield is easily affected by soil moisture stress in semi-arid climate. Good vertisol management options that conserve moisture during dry spell period and drain excess moisture during wet periods is vital. Study area has limited rainfall therefore evidences on effect of land configuration ways on soil moisture and sesame yield is critical. A field investigation was conducted at Humera Agricultural Research Center (HuARC) during 2016 growing season in vertisol soil type. The experiment was laid out by randomized complete block design (RCBD) with three replication that consists of three land configuration ways or methods namely flat, ridge and furrow, and bed furrow. Sesame variety, Setit-1, was sown with $40 \mathrm{~cm}$ and $10 \mathrm{~cm}$ spacing between rows and plants respectively. The analysis revealed that land configuration methods had a significant effect on soil moisture and agronomic parameter. The highest sesame seed yield $\left(558 \mathrm{~kg} \mathrm{ha}^{-1}\right)$ was recorded at ridge and furrow, while the lowest $\left(400 \mathrm{~kg} \mathrm{ha}^{-1}\right)$ was found at the flat land configuration method. The ridge and furrow methods conserved best soil moisture for highest plant and seed yield performance.
\end{abstract}

\section{Introduction}

Sesame (Sesamum indicum L.) belong to the Pedaliaceae family (Vittori Gouveia et al., 2016) and one of the oldest oilseed crops (Pham et al., 2010). It is an erect herbaceous annual plant with either single-stemmed or branched growth habits. It grows up to $2 \mathrm{~m}$ height (Pham et al., 2010) and with a large taproot of $90 \mathrm{~cm}$ (Ashri and Singh, 2007). Sesame is a warm-season oil crop which is chiefly adapted to areas with an extended growing period and well-aerated soils. Sesame performs well in a slightly acidic to alkaline soils ( $\mathrm{pH} 5-8$ ) with moderate fertility (Mohammed and Hamza, 2008). Sesame diversity centers have been identified in India, China, Central Asia, Near East, and Ethiopia (Zeven and Zhukovsky, 1975), also reported that the origin would be in Africa (Brar and Ahuja, 1980; Ram et al., 1990). Culinary use of sesame seed includes decoration of bread and cookies, to produce paste added to certain dishes, and in desserts such as sweetened tahini. Sesame oil is a cooking and salad oil. In association with human health, sesame seeds have numerous advantages to prevent such as cancer and heart disease, which is caused by inhibition of vitamin E, could be mediated by sesame seed (Elleuch et al., 2011).

Sesame grain yield is easily affected by soil moisture stress in semi-arid climate. Study area has limited rainfall which is erratic nature and uneven distribution which results in soil moisture stress when accompanied by high evaporation. Similarly, moisture stress could have resulted when transpiration of water exceeding the rate of absorption, thereby acting directly on the water balance in plants (Costa et al., 2008) is critical. This may also add damage to sesame, which can be more or less severe, depending on the intensity of the stress, exposure time, and stage of development of the crop. Like most other crops, sesame's early growth phases, germination and seedling (Boureima et al., 2011) periods and reproductive stage (Nilanthi et al., 2015) highly influenced by moisture stress. The cultural practices such as weeding and tillage have a great influence on sesame crop performance and yield. So searching a good management option that conserve moisture during dry period and drain excess moisture during wet periods is vital. Therefore, three land configuration ways namely flat, ridge and furrow, and bed furrow to conserve soil moisture were compared on their effect on sesame productivity.

\section{Materials and methods}

\subsection{Area description}

This experiment was conducted in 2016 growing season at Humera Agricultural Research Center (HuARC) located between $13^{\circ} 14^{\prime}$ to $14^{\circ} 27^{\prime} \mathrm{N}$ and $36^{\circ} 27^{\prime}$ to $37^{\circ} 32^{\prime} \mathrm{E}$. The experiment area soil is vertisol which is sticky during wet and cracked during dry period (EARO, 2002). The annual rainfall ranges between 400 to $600 \mathrm{~mm}$ and most of the rain appear from June to September. The annual mean temperature is $27.6{ }^{\circ} \mathrm{C}$. It is also characterized by hot temperature, erratic rainfall, a vast area of plain low lands suitable for large scale, and subsistence agriculture including 
crops and livestock.

The experiment was carried out in a randomized complete block design (RCBD) with three replicates. The tested treatments were ridge and furrow at a depth of $30 \mathrm{~cm}$, bed furrow at $0.8 \mathrm{~m}$ with depths of $30 \mathrm{~cm}$ between farrows and flat land configuration method. Land configuration is arrangement of the soil that helps for maximizing rainfall infiltration, minimizing erosion, reduce total runoff, facilitates drainage and ultimately improves water use efficiency. Modification of land through broad bed and furrow and ridges and furrows would reduce the soil related problems and improve the crop growth and yield. Ridge and furrow is a type of earthwork found in fields. It gives the surface of the ground a wavy corrugated effect, like corduroy, and consists of linear ridges or humps with shallow ditches between. Bed furrow is raised land configuration system helps the soil to preserve the water level for a longer period holding moisture intact, the bed stimulates crop's growth. Flat land configuration has a flat surface on which seeds are placed. The total plot area was 6 $\mathrm{m}^{2}$ and the net plot area was $3.6 \mathrm{~m}^{2}$. The distance between the plot and the block was $1 \mathrm{~m}$ and $1.5 \mathrm{~m}$, respectively. Setit1 sesame variety was used as sowing material with row to row $40 \mathrm{~cm}$, plant to plant $10 \mathrm{~cm}$. Setit-1 has 80.83 day of maturity, 30.50 number of capsule per plant, 3.21 number of branches per plant, $49.97 \mathrm{~cm}$ length of capsule bearing zone, $2.94 \mathrm{~g}$ thousand seed weight, $745.10 \mathrm{~kg} \mathrm{ha}^{-1}$ seed yield and $50.30 \%$ oil content (Yirga et al., 2019). The field was plowed twice with a tractor-drawn disc harrow and provided with $100 \mathrm{~kg} \mathrm{ha}^{-1}$ of NPS (19N-38P2O5 + 7S) and $50 \mathrm{~kg} \mathrm{ha}^{-1}$ of urea fertilizer containing $46 \% \mathrm{~N}$. The urea was applied in split form $25 \mathrm{~kg} \mathrm{ha}^{-1}$ at sowing and $25 \mathrm{~kg} \mathrm{ha}^{-1}$ at flower initiation. Webworm pest, which causes a potential yield reduction was controlled with the application of dimethoate (Gebregergis et al., 2018).

\subsection{Data collection}

\subsubsection{Crop performance}

\section{a. Phonological data}

The flowering (50\%) and maturity (90\%) were two important phonological data recorded. Maturity was measured when the crop leaves turned yellow and most of the lower capsules started to open. Each phenological stage was determined by visual observation.

\section{b. Yield and yield components}

Number of branches per plant, number of capsules per plant and number of seeds per capsule were counted from five randomly selected plants per plot and plant height was measured from five plants per plot. After harvesting, biomass was allowed to dry by setting the bundles upright until all capsules opened. Threshing was done by hitting inverted bundles for a few times until all seeds dropped from the capsules (Terefe et al., 2012).

To determine the number of seeds per capsule, the seeds of three capsules (lower, medium, and uppermost position on the plant) from each of five plants were counted. Thousand seed weights were determined by counting and weighing 1000 seeds from each plot after sun drying. The Seed yield of each plot was weighed in grams and converted to an area basis to determine the yield per hectare in $\mathrm{kg} \mathrm{ha}^{-1}$.

\subsubsection{Soil moisture data}

Fresh soil was sampled from depths of Upper (0-0.2 m), Medium (0.21-0.4 m), and Lower (0.41-0.6 m) in the experimental field every two weeks. Sampled fresh weight was weighed and dried in an oven for 24 hours at $105^{\circ} \mathrm{C}$. The gravimetric soil water content was determined using equation 1 after weighing the oven-dried soil sample. The soil moisture content that was derived from the depths of 0$0.2 \mathrm{~m}, 0.21-0.4 \mathrm{~m}$, and $0.41-0.6 \mathrm{~m}$ were added to attain root depth soil moisture content.

Soil moisture content $(\%)=\frac{\text { fresh soil weight }- \text { dry soil weight }}{\text { dry soil weight }} \times 100 \ldots \ldots$ (Eq. 1)

\subsection{Data analysis}

The experimental data collected was analyzed statically by the technique of an analysis of variance and mean that showed significant difference was separated with mean comparison test using Duncan multiple range test (DMRT) using the least significant difference of 5\% (Duncan, 1955).

\section{Results and discussion}

\subsection{Outcome of land configuration method on SMC at different soil depth and growth phase}

The analysis of variance revealed that land configuration methods have an insignificant difference $(p>0.05)$ on soil moisture content (SMC) for 15 days after sowing at entire soil depth. Though statically similar in the upper soil depth, bed furrow land configuration method conserved best soil moisture but in the medium soil depth ridge and furrow conserved highest soil moisture than the rest land configuration methods (Table 1). This period of sesame is known as a seedling to the vegetative stage (Langham et al., 2008). This conserved moisture was vital for good germination and seedling growth. This finding is similar to (Keteku et al., 2020) who noted the highest soil moisture at ridge and furrow and bed furrow land configuration methods. This agree with (Reddy et al., 2009) who noted the highest moisture conservation efficiency compared to the flat land configuration at 25 days after sowing. A similar result was suggested by Abrha (2018).

The analysis indicated that land configuration ways showed an insignificant difference $(\mathrm{p}>0.05)$ on soil moisture in all soil depths except in medium soil depth during 45 DAS. In the medium soil depth, best moisture (29.3\%) was conserved at bed furrow; though statically at par with the ridge and furrow, while the poorest $(24.1 \%)$ was conserved at the flat land configuration (Table 1). This growth period of sesame known as flowering to grain filling stage (Langham et al., 2008). The best moisture conserved at the bed furrow and ridge and furrow land configuration methods maintain a favorable environment that helps sesame plants produce the highest number and quality capsules. These findings agree with (Reddy et al., 2009) who reported maximum soil moisture conservation efficiency of ridge and furrow compared to the flat land configuration method during 50 days after sowing. Similar results were reported by Abrha (2018) and Keteku et al., (2020). 


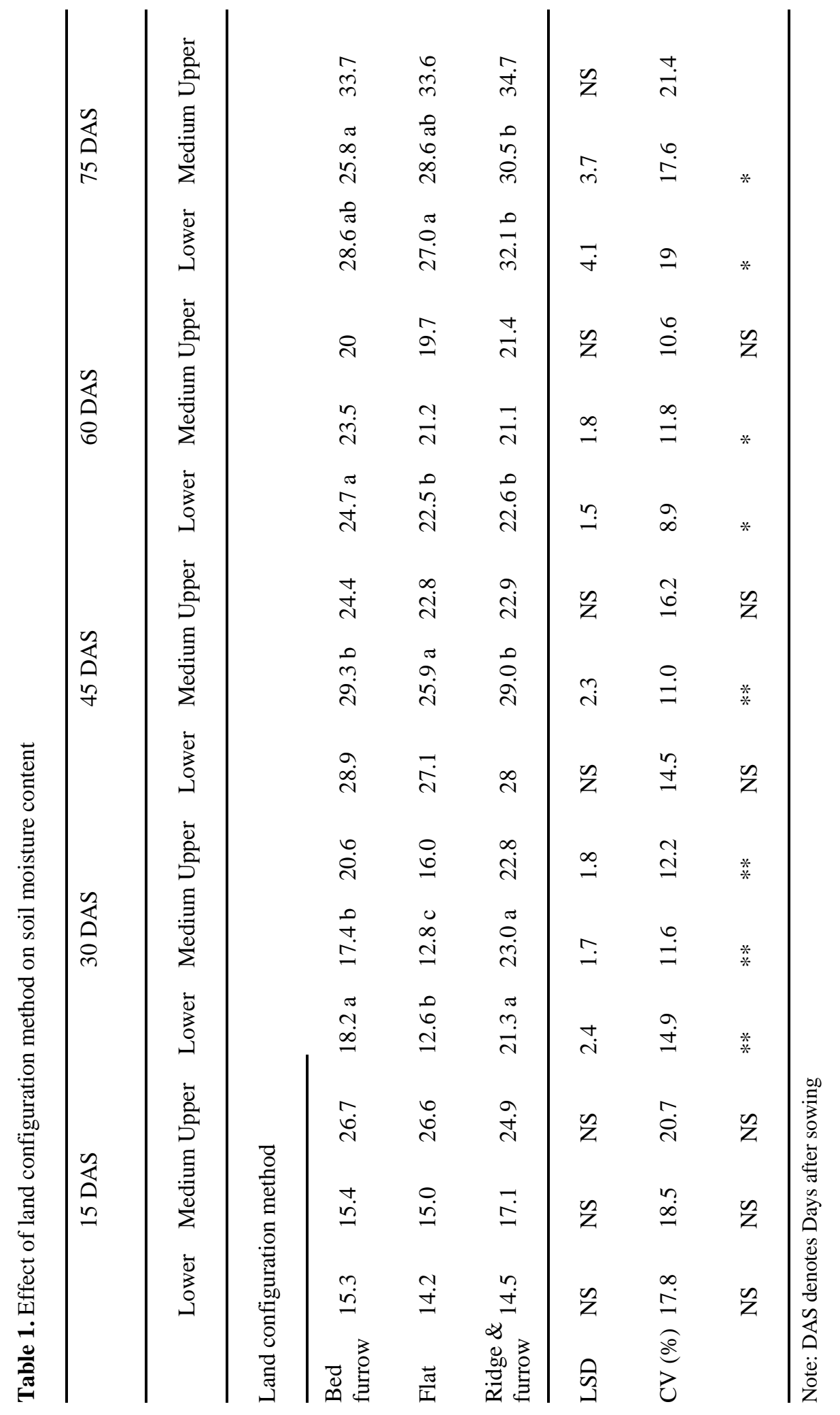


The analysis of variance show, land configuration methods revealed a significant difference $(\mathrm{p}<0.01)$ on soil moisture in entire depths except for upper soil depth during 60 days after sowing. In the medium soil depth, the highest moisture $(23.5 \%)$ was conserved at the bed furrow, while the poorest $(21.1 \%)$ was conserved at the ridge and furrow; though statically similar with the flat land configuration method (Table 1). In the lower soil depth, the highest soil moisture $(24.7 \%)$ was conserved at the Bed furrow while the lowest $(22.5 \%)$ was conserved at flat; even if statically similar to the ridge and furrow (Table 1). This growth period of sesame called grain filling stage. Soil moisture conserved at this growth phase was essential in facilitating the translocation of assimilates from the sink to the source (Langham et al., 2008). This results agrees with (Reddy et al., 2009) who noted maximum soil moisture conserved at the ridge and furrow land configuration method is vital to support grain filling stage.

Land configuration methods had a highly significant difference $(\mathrm{p}<0.01)$ on soil moisture in all depths during 75 days after sowing except upper soil depth. From 0.21-0.4 m soil depth, the maximum moisture $(30.5 \%)$ was conserved at the ridge and furrow; even if statically similar to the flat, whereas the minimum moisture $(25.8 \%)$ was conserved at bed furrow land configuration method (Table 1). Highest soil moisture conserved in the lower soil depth from ridge and furrow though statically similar with the flat land configuration method (Table 1). This essential growth stage in sesame cultivation called grain filling to physiological maturity (Langham et al., 2008). The moisture conserved in this stage was vital in the grain filling through translocation of assimilates and influencing the physiological maturity.
The maximum moisture conserved at the ridge and furrow land configuration method during grain filling and maturity stage was vitally important in producing healthy and productive plant (Reddy et al., 2009).

\subsection{Agronomic traits of sesame}

\subsubsection{Sesame population density}

The characteristics of the vertisol soil are sticky during rain, crack during the absence of rain and have impact on maintaining the exact stand count of a given area (Virmani et al., 1982). The number of plants per square meter is essential for determining appropriate final yield. The current study investigated land configuration methods showed a highly significant effect $(\mathrm{p}<0.01)$ on the sesame population per meter square (Table 2). The highest population of sesame (23 plants $\mathrm{m}^{-2}$ ) plant per meter square were recorded at the

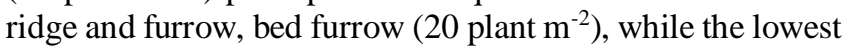
population of sesame (19 plant $\left.\mathrm{m}^{-2}\right)$ were recorded at the flatland configuration method (Table 2). Higher population may be due to better water conservation. The lowest plant population in the flatland configuration method could be due to its poor performance in conserving soil moisture and cracking nature of the soil as a result plant that were grown on this land configuration method had shown a poor survival rate. This lower population density per unit area stated in the flat land configuration method could be due to high cracking nature and deficit of soil moisture. This result in line with (El Abbas Doka et al., 2017) who reported continuous cropping of vertisol through time leads to intensified cracking which could have a great influence on crop stand establishment and productivity.

Table 2. Effect of land configuration method on yield and yield component

\begin{tabular}{|c|c|c|c|c|c|c|c|c|c|}
\hline Treatments & $\mathrm{DF}$ & DM & BPP & $\mathrm{PH}$ & $\mathrm{NCP}$ & NSPC & TSW & Pop (plant $\mathrm{m}^{-2}$ ) & GY $\left(\mathrm{kg} \mathrm{ha}^{-1}\right)$ \\
\hline \multicolumn{10}{|c|}{ Land configuration method } \\
\hline Bed furrow & 41 & $92.7^{\mathrm{a}}$ & 2.6 & $79^{\mathrm{a}}$ & $32.5^{\mathrm{ab}}$ & $40^{\mathrm{a}}$ & $3.4^{\mathrm{a}}$ & $20.3^{\mathrm{b}}$ & $464^{\mathrm{b}}$ \\
\hline Flat & 39 & $89.8^{\mathrm{b}}$ & 2.9 & $70^{\mathrm{b}}$ & $29.3^{\mathrm{b}}$ & $38^{\mathrm{a}}$ & $3.3^{\mathrm{a}}$ & $19.4^{\mathrm{b}}$ & $400^{c}$ \\
\hline Ridge and furrow & 41 & $94.5^{\mathrm{a}}$ & 2.5 & $76^{\mathrm{a}}$ & $33.9^{\mathrm{a}}$ & $42^{\mathrm{a}}$ & $3.5^{\mathrm{a}}$ & $22.9^{\mathrm{a}}$ & $558^{\mathrm{a}}$ \\
\hline $\mathrm{CV}(\%)$ & 3.5 & 1 & 12 & 2.1 & 4.4 & 5 & 4.0 & 2.0 & 2.2 \\
\hline LSD (0.05) & 3 & 1.9 & 0.7 & 1.0 & 9.5 & 4.5 & 0.3 & 0.9 & 23.7 \\
\hline
\end{tabular}

Note: DF stands for Days of 50\% flowering, DM stands for Days of $90 \%$ maturity, BPP stands for number of branches per plant,, PH stand for plant height, NCP stands for number of capsule per plant, NSPC stands number of seeds per capsule, TSW stands for total seed weight, Pop stands for population, GY stand for grain yield.

\subsubsection{Flowering days}

The current finding illustrated an insignificant effect ( $p>0.05$ ) of land configuration practices on the $50 \%$ flowering. However, the ridge and furrow and bed furrow took a longer period (41 days) for the $50 \%$ flowering, while the lowest was days to the $50 \%$ flowering took at flat land configuration (Table 2). The shortest period of flowering on the flat land configuration method could be due to the moisture conserved during this period (Section 3.1.2) was the lowest compared bed farrow and ridge and furrow land configuration method. This less moisture conserved at this land configuration technique resulted in early flowering. This result in line with Abrha (2018), delay flowering period on the tied ridge due to better moisture conserved compared to the flat land configuration method. Accordingly, (Sukanya and Mehndran, 2018) reported sesame is susceptible to water stress during flowering.

\subsubsection{Maturity days}

This outcome confirms land configuration method showed a significant effect $(\mathrm{p}<0.05)$ on the period that takes for $90 \%$ maturity. Even though the ridge and furrow and the bed furrow land configuration indicated an insignificant difference statistically the longer time to maturity (94.5 days) was recorded at the ridge and furrow compared to the flat that shows early maturity (90 days) (Table 2 ). Delaying time for sesame maturity at ridge and the bed furrow could be in relation to sufficient moisture conservation in all growth 
stages (Section 3.1) in their furrow structures which is essential for healthy plant growth and performance.

\subsubsection{Number of branches per plant}

The current result indicated that the land configuration methods didn't show a significant difference $(p>0.05)$ on the number of branches per plant. However, the highest number of branches (2.9) was recorded under the bed furrow and the lowest (2.5) was recorded under the flat land configuration method (Table 2).

\subsubsection{Plant height $(\mathrm{cm})$}

Plant height is a yield component that is affected by biotic and abiotic stress. The biotic stresses that affect sesame plant height are weed competition, disease, and pests while the abiotic stresses are waterlogging and deficit. The land configuration practices have a vital role in moisture conservation. The study revealed that plant height showed a significant difference at $(\mathrm{p}<0.05)$ among treatments. The maximum plant height $(79 \mathrm{~cm})$ was measured at the bed furrow though statically similar with the ridge and furrow, while the minimum plant height $(70 \mathrm{~cm})$ recorded at the flat land configuration method (Table 2). This could be in relation to the moisture conserved at the bed farrow and the ridge maintains good plant performance (Section 3.1). This finding is the same to (Abrha, 2018) who recorded the highest plant height at tie ridge land configuration method.

\subsubsection{Number of capsules per plant}

This is an important parameter that determines the final grain yield of sesame crop. Sesame number of capsules is affected by moisture stress in both conditions at logging and deficit. Lack of moisture could reduce capsule numbers by affecting the translocation and transportation of assimilates and nutrients. This affects flower development for capsules formation and as the stress becomes severe, it leads to flower abortion. This condition makes sesame to produce lower number of capsule of smaller size. The present result stated that the land configuration methods showed a significant difference $(\mathrm{p}<0.05)$ on capsules number per plant. The highest number of capsules (33.9) was recorded at the ridge and furrow land configuration technique, even though insignificantly differ from bed furrow land configuration, whereas the lowest (29.3) was recorded at flat (Table 2). This could be due to the conserved moisture in all sesame growth phases that had a role in converting all sesame flowers to capsules. This finding is in harmony with Malik et al., (2003) who noted the highest number of capsules per sesame plant (94) under raised bed land configuration, while the lowest number of capsules per sesame plant (92) under flat planting. Accordingly, Kadkhodaie et al., (2014) noted drought stress mainly when it occurs during the flowering phase severely affects sesame production. Besides, Abrha, (2018) noted tied ridge produces the highest number of capsules per plant compared to the flat land configuration.

\subsubsection{Number of seeds per capsule}

Similar to other parameters, the number of seeds per capsule is an important sesame parameter that determines the final yield and it is affected by different stress. The current investigation revealed that the land configuration methods didn't show a significant difference $(p>0.05)$ on the number of seeds per capsule. However, the highest number of seeds per capsule (42) was recorded at the ridge and furrow, while the lowest (38) was recorded at the flatland configuration method (Table 2). This finding is in line with (Malik et al., 2003) that reported the highest number of seeds per capsule (63) under the ridge land configuration.

\subsubsection{Thousand seed weight}

The analysis showed insignificant difference $(p>0.05)$ between the land configuration techniques for thousand seed weight. However, the highest thousand seed weight $(3.5 \mathrm{~g})$ was recorded at the ridge and furrow, but the lowest $(3.3 \mathrm{~g})$ was fund at the flatland configuration. This is in line with Malik et al., (2003) who noted the highest thousand seed weight of sesame ( $3.3 \mathrm{~g})$ under the ridge land configuration and the lowest thousand seed weight (3.1g) under the flat planting (Table 2). A similar result also was noted by Abrha, (2018).

\subsubsection{Effect of land configuration method on grain yield}

Land configuration methods have a vital role in boosting yield and yield components of different crops. This study showed significant effects $(\mathrm{p}<0.05)$ of land configuration ways on seed yield. Better seed yield (558 kg ha-1) was noted from the ridge and furrow land configuration way, while the lowest (400 kg ha-1) was recorded under the flat (Table 2). The highest yield obtained under the ridge and furrow could be due to moisture conserved by the structure and this promotes the number of branches, plant height, number of capsules per plant, and number of seeds per capsule. This finding is in harmony with Malik et al., (2003) who reported highest yield under the ridge land configuration method in sunflower. Similar results were also reported by Reddy et al., (2009) and Rajput et al., (2009).

\section{Conclusion}

The land configuration methods have a direct effect on soil moisture and sesame seed yield. The current result showed that the land configuration methods have a significant influence on soil moisture and sesame yield. Particularly, Ridge and farrow land configuration methods had a great influence on soil water content and sesame yield on the entire growth stage of the crop. So farmers should practice ridge land configuration under moisture stress conditions to optimize yield.

\section{Acknowledgment}

The authors express thanks to Tigray Agricultural Research Institute, Humera Agricultural Research Center, Mekelle University, and Sesame Business Network Project for allocating funding of this research.

\section{Authors' Contributions}

Goitom Teame: participated in data collection, analysis, description, and draft the manuscript. Alemtsehay Tsegay: participated in supervision of the work starting from the proposal up to final draft: Dawit Weldearegay: supervised, edited and revised the manuscript. All authors accepted the manuscript.

\section{Conflict of interest}

The authors declare that they have no conflict of interest. 


\section{Funding}

Tigray Agricultural Research Institute, Humera Agricultural Research Center

\section{Abbreviations}

NPS Nitrogen, Phosphorus and Sulfur

SMC Soil Moisture Content

DAS Days after Sowing

\section{References}

Abrha, H. (2018). Grain yield and economic returns of sesame (Sesamum indicum L.) induced by in-situ moisture conservation and sulfur fertilization on vertisol of Western Tigray, Ethiopia. Asian Soil Research Journal, 1(2): 1-15.

Ashri, A., \& Singh, R. (2007). Sesame (Sesamum indicum L.). Genetics resources chromosome engineering and crop improvement. Oilseed Crop, 4: 231-289.

Boureima, S., Eyletters, M., Diouf, M., Diop, T. A., \& Van Damme, P. (2011). Sensitivity of seed germination and seedling radicle growth to drought stress in sesame (Sesamum indicum L.). Research Journal of Environmental Sciences, 5(6): 557-564.

Brar, G., \& Ahuja, K. (1980). Sesame: its culture, genetics, breeding and biochemistry. Annual Reviews of Plant Sciences, 1: 245-313.

Costa, R., Lobato, A. K. S., Oliveira Neto, C. F., Maia, P. S. P., Alves, G., \& Laughinghouse, H. D. (2008). Biochemical and physiological responses in two Vigna unguiculata (L.) Walp. cultivars under water stress. Journal of Agronomy, 7(1): 98101.

Duncan, D. B. (1955). Multiple range and multiple $F$ tests. Biometrics, 11: 1-41.

El Abbas Doka, M. A., Aitken, J., \& Munro N. R. (2017). Studying the Characteristics of Vertisols to Set Up Field Management Practices at Dinder Area (Sennar State-Sudan). Advances in Image and Video Processing, 5(5): 21-21.

Elleuch, M., Bedigian, D., \& Zitoun, A. (2011). Sesame (Sesamum indicum L.) seeds in food, nutrition, and health. In Nuts And Seeds in Health And Disease Prevention (pp. 1029-1036). Academic Press.

Ethiopian Agrcicultual Research Organization (EARO) (2002). An assessment of the agricultural production base, technological packages and innovation and intervention strategies for commercial farmers in Kafta-Humera Woreda of Tigray Regional State, Addis Ababa.

Gebregergis, Z., Assefa, D., \& Fitwy I. (2018). Sesame sowing date and insecticide application frequency to control sesame webworm Antigastra catalaunalis (Duponchel) in Humera, Northern Ethiopia. Agriculture \& Food Security, 7(1): 1-39.

Terefe, G., Wakjira, A., Berhe, M., \& Tadesse, H. (2012). Sesame production manual. EIAR, 1-46.

Kadkhodaie, A., Morteza Zahedi, M., Razmjoo, J., \& Pessarakli, M. (2014). Changes in some anti-oxidative enzymes and physiological indices among sesame genotypes (Sesamum indicum L.) in response to soil water deficits under field conditions. Acta Physiologiae Plantarum, 36(3): 641-650.

Keteku, A.K., Kadam, A.K., Dana, S., Blege, P.K. (2020). Influence of land configuration and fertilization techniques on soybean (Glycine max (L.) Merrill.) productivity, soil moisture and fertility. Acta Agriculturae Slovenica, 115(1): 79-88.

Mohammed, M., \& Hamza, Z. (2008). Physicochemical properties of oil extracts from Sesamum Indicum L. seeds grown in Jigawa State-Nigeria. Journal of Applied Sciences and Environmental Management, 12(2):99-101.

Nilanthi, D., Alawathugoda, C., \& Ranawake A. (2015). Effects of water stress on yield and some yield components of three selected oil crops; Groundnut (Arachis hypogea L.), sunflower (Helianthus annus L.) and sesame (Sesamum indicum L.). International Journal of Scientific and Research Publications, 5(2): 2250-3153.

Langham, D.R., Riney, J., Smith, G., Wiemers, T. (2008). Sesame grower guide. Sesaco sesame coordinators, Lubbock, TX. Retrieved Decemeber, 18: 2014. http://www.sesaco.net.

Malik, M. A., Saleem, M. F., Cheema, M. A., \& Ahmed, S. (2003). Influence of different nitrogen levels on productivity of sesame (Sesamum indicum L.) under varying planting patterns. International Journal of Agriculture Biology, 5(4): 490-492.

Pham, T. D., Thi Nguyen, T. D., Carlsson, A. S., \& Bui, T. M. (2010). Morphological evaluation of sesame (Sesamum indicum) varieties from different origins. Australian Journal of Crop Science, 4(7), 498-504.

Rajput, R., Kauraw, D. L., Bhatnagar, R. K., Bhavsar, M., Velayutham, M., Lal, R. (2009). Sustainable management of vertisols in central India. Journal of Crop Improvement, 23(2): 119-135.

Ram, R., Catlin, D., Romero, J., \& Cowley C. (1990). Sesame: New approaches for crop improvement. Advances in new crops. Timber Press, Portland, p. 225-228.

Reddy, B. S., Maruthi, V., Adaje, R. V., \& Madal, U. K. (2009). Effect of different land configuration practices on productivity of sorghum-pigeonpea intercropping system in Shallow Alfisols. Indian Journal of Dryland Agricultural Research and Development, 24(1): 57-62.

Sukanya, M., \& Mahendran, S. (2018). Impact of moisture stress at flowering stage on the growth and yield of selected groundnut (Arachis hypogaea L.) cultivars. International Journal of Research Publications, 4(1): 7-7.

Virmani, S. M., Sahrawat, K. C., \& Burford, J. R. (1982). Physical and Chemical properties of Vertisols and their management in Vertisols and Rice Soils of the Tropics, Transactions of the Twelfth International Congress of Soil Science, Symposia Papers II, 8-16 Feb, 1982, pp. 94-118.

Vittori Gouveia, L. d. A., Cardoso, C. A., Oliveira, M. D., Rosa, G., \& Moreira, A. S. B. (2016). Effects of the intake of sesame seeds (Sesamum indicum L.) and derivatives on oxidative stress: A systematic review. Journal of Medicinal Food, 19(4): 337-345.

Yirga, K., Firew, M., Eyasu. (2019). Evaluation and Registration of White Seeded Sesame Variety (Sesamum indicum L.) in Western Tigray, Ethiopia. International Journal of Research in Agriculture and Forestry, 6(9): 23-28.

Zeven, A. C., \& Zhukovsky, P. M. (1975). Dictionary of cultivated plants and their centers of diversity. Center for Agricultural Publishing and Documentation, Wageningen, the Netherlands. Pp 62-63. 